\title{
Marketing Strategies in the Formation of Tourism Clusters
}

\author{
Dostoevsky Omsk State University, Omsk, 644077, Russia \\ *Corresponding author. Email: albkis@mail.ru
}

A.M. Kiseleva* O.V. Gokova

\begin{abstract}
The article makes a case for using marketing strategies in the practice if the functioning of the tourism industry and also for its applications in the cluster policy of the regional government. Currently, in the modern economy, clusters are becoming an important source of leverage at regional economic development. The relationship between tourism industry marketing and cluster initiatives allows the increasing efficiency of this sphere in market conditions. Marketing strategies make it possible to assess the competitiveness of the region and the market potential of the tourism industry for the formation and development of clusters.
\end{abstract}

Keywords: marketing strategies, tourism marketing, cluster policy, investment potential, tourism clusters

\section{INTRODUCTION}

In the Russian Federation the tourism industry is a mandatory area of the spatial development of regions. It is representing a special form of territorial development which is characterized by economic, cultural, national, ethnic, environmental and territorial traditions and characteristics. The tourism sector participates in the formation of territorial budgets and the entrepreneurial environment and reflects the multiplier effect on other sectors of universal participation in regional development: food and agriculture, transport and construction. If you allocate types of tourist specialization (educational, business, health-improving, etc.), the number of industries included in the range of influence of the tourism industry increases. From this perspective, the development of integrated marketing strategies, including those based on the territory of local communities, is a necessary aspect of spatial management. For the competitiveness of the tourism industry in the context of one region, attention should be paid not only to individual tourism organizations but also to an integrated approach to balancing the development of the entire industry.

Marketing of the territory, representing an important element of strategic territorial management, due to the influence of investment needs, allows forming the subjectobject position of the authorities of the subject of the Russian Federation on issues of improvement of the investment image of the region. This marketing direction in relation to territories of regions and cities is paid attention by such Russian and foreign specialists as D. Vizgalov [2], P. Kotler, D. Haider, I. Rein [22], T. Sachuk [21], etc. One of the types of marketing of the territory is tourism marketing, the essence of which is to increase the number of work-places and stimulate the development of a wide range of industries in the service sector, from hotel to transport infrastructure and entertainment [2]. The tourist aspect in marketing strategies was raised by A. Pankrukhin [23], A. Simavonyan[24], F. Kotler, K. Asplund, I. Rein, D. Haider [25], etc.

The comprehensive marketing strategies help to assess and to put into practice the competitive advantage of organizations of the touristic industry within the established characteristics of the area and its potential. In the current economic conditions of limited and insufficient resources, the authorities of the regions have a need to cluster the tourism industry for profit on the basis of the close location of economic entities involved in the tourism business. This makes it possible to form tourist destruction in the most balanced form, reflecting the specificity and uniqueness of the tourist offer. The services sector is a rather vulnerable area in the practice of cluster initiatives and marketing mechanisms allow to approach the research of competitive positions of the Territory in an integrated manner. Cluster development issues were first raised by M. Porter [14]. Further, domestic and foreign scientists made a significant contribution to cluster research and justification of the cluster approach of $\mathrm{N}$. Bondarenko [16], P. Galvin [15], T. Danko, E. Kutsenko [17], Ö. Sölvell, G. Lindqvist, C. Ketels [18], J. Swords [19], O. Kostenko [20] and a number of others. When deciding on the formation of cluster policy of the region, the authorities of the subject of the Russian Federation pursue the goal of optimal consideration of the geographical position of the region, effective use of the potential of the territory and society, including material and technical and property, financial and economic, personnel and intellectual, information and regulatory resources [1]. The integration of territorial capacity and resources both within a region and in interregional cooperation processes should be based on the principles of Territory marketing. The inclusion of marketing strategies in the implementation of the cluster initiative of the tourism industry determined the 
problem of research and the relevance of addressing this issue.

As a hypothesis, we can consider the influence of marketing strategies on the development processes of the tourism industry through cluster initiatives, which were not yet reflected in the scientific community. From this point of view, our study has tried to determine the importance and feasibility of using this tool in regional tourism policy through the clustering of economic entities associated with the tourism industry. The tourist product of the territory, oriented to resource opportunities, is determined through a complex of attractions of destruction (centers and events of attraction of tourists in the territory), infrastructure and organizational elements. The marketing of tourism strategically provides conditions of competitiveness and attractiveness of the region, its socioeconomic development on the basis of the research of processes of formation and realization of tourism clusters.

\section{BACKGROUND}

The development of the tourism industry in Russia indicates the existence of numerous problems in it. One of the objective contradictions is an absence at the level of local territories of a comprehensive marketing strategy, which allows concentrating resource efforts on organizations connected in a certain way with the tourist business, and provides for the development and promotion of the domestic tourist product. Measures to enhance the territory's competitive position through cluster initiatives are an important strategic tool for tourism marketing. This is especially important for those subjects of the Russian Federation that have the necessary characteristics for the registration of cluster projects in entertainment tourism. At the same time, in the cluster policy of any region, business tourism is increasingly being embodied in the analysis and evaluation of the investment attractiveness of the territory and its competitive advantages.

The investigation of the regional market potential as part of the development of the marketing strategies makes it possible to determine tourism products and their volume, the quality and cost, to conduct a cost-benefit analysis of its production and sales, to ensure the procedures of positioning and promoting in a specified regional and interregional market segment and among specific consumer groups. Taking into account regional competitive advantages, geographical and natural peculiarities of the location of the region, established market and power-management communications, needs of the region in certain territorial products, sectoral specifics, and resource opportunities become a prerequisite. The advantages of the cluster approach to regional development are determined by the possibility to consider the activities of enterprises of different industries, in particular, the tourist sphere, systemically, as well as the results of their activities in the form of the production of a regional product, increase the profitability of the budget, achieve social effect [10, p. 185]. The marketing product, in this case, is a set of proposals for the tourist market of the region, which can form a certain cluster, as well as the established and functioning tourist cluster in the region. Pricing of the tourist product takes place on the basis of proposals of individual economic entities, whose activities are due to the specificity of tourist growth, and their infrastructure capabilities, taking into account the peculiarities of the territory and its orientation to certain types of tourism, consumer interest in the unique characteristics of the region. The contribution to the economy of the region is also determined within the framework of the clustering of the tourism industry, which determines the need to monitor the price of the tourist product.

According to the annual rating of tourist attractiveness of the regions, the subjects of the Russian Federation are systematized into "gold", "silver", "bronze" groups, which allow to assess the level of regional development of the tourism industry on the basis of 10 criteria (level of development of hotel business and infrastructure; The importance of the tourism industry in the region's economy; a turn of tourist services; Popularity of the region among Russians, etc.) (Table 1). The criterion analysis allows assessing the success and stability of the subject of the Russian Federation on the tourist market in the dynamics, since 2015, to conclude on the need for a strategic approach to the clustering of this industry in a specific region.

The elements of the cluster policy are defined by the federal level of power in the Concept of Long-term Social and Economic Development of the Russian Federation until 2030. Regional cluster policies are formulated in the strategies of federal districts and constituent entities of the Russian Federation, are to be implemented by the relevant executive bodies and cluster development centers formed in the territories. According to the forecast, experts of Strategy Partners Group for 2028 the number of tourist arrivals to the regions of the Russian Federation under the worst commodity scenario of the Russian economy will grow almost 3 times (from 45 million people in 2006 up to 131 million people in 2028), under the industrial scenario - up to 160 million people; with innovative development up to 191 million people [3].

The analytical work of regional authorities entails the need for regular monitoring of the socio-economic situation of the territories, which should ensure the information support for the development of a marketing program to increase the territory's competitiveness in tourism practice. This should take into account the strategic territorial management system in the region, the conditions of instability and uncertainty of the factors of influence of the external environment. The tourist potential of the territory is also assessed by elements of its attractiveness, such as socio-economic and geographical location, natural and climatic characteristics, entrepreneurial environment, architectural, construction and landscape appearance of cities, level of planning rationality, transport, information, entertainment and leisure infrastructure, products of local organizations and enterprises, etc. 
Table 1 National tourism ratings of the subjects of the Russian Federation [11]

\begin{tabular}{|c|c|c|c|c|c|}
\hline \multirow{2}{*}{$\begin{array}{l}\text { Rating } \\
\text { place }\end{array}$} & \multicolumn{5}{|c|}{ Rating years / The first top 5 regions of the Russian Federation in each group } \\
\hline & 2015 & 2016 & 2017 & 2018 & 2019 \\
\hline \multicolumn{6}{|c|}{ "Gold" group } \\
\hline 1 & Krasnodar region & Moscow & Krasnodar region & Moscow & Moscow \\
\hline 2 & Saint-Petersburg & Saint-Petersburg & Moscow & Krasnodar region & Saint-Petersburg \\
\hline 3 & Moscow & Krasnodar region & Moscow region & Moscow region & Moscow region \\
\hline 4 & Republic of Crimea & Republic of Crimea & Republic of Crimea & Saint-Petersburg & Krasnodar region \\
\hline 5 & Moscow region & Moscow region & Saint-Petersburg & $\begin{array}{l}\text { Republic of } \\
\text { Crimea }\end{array}$ & $\begin{array}{l}\text { Republic of } \\
\text { Crimea }\end{array}$ \\
\hline \multicolumn{6}{|c|}{ "Silver" group } \\
\hline 1 & Novgorod region & Republic of Karelia & Vladimir region & Kaliningrad region & Perm region \\
\hline 2 & Kamchatka region & Rostov region & Tyumen region & Vladimir region & $\begin{array}{l}\text { Kaliningrad } \\
\text { region }\end{array}$ \\
\hline 3 & Vladimir region & Novosibirsk region & Samara region & Sakhalin region & Sakhalin region \\
\hline 4 & $\begin{array}{l}\text { Republic of } \\
\text { Bashkortostan }\end{array}$ & Sakhalin region & Sakhalin region & Tula region & Tula region \\
\hline 5 & Tyumen region & Murmansk region & Leningrad region & Leningrad region & Yaroslavl region \\
\hline \multicolumn{6}{|c|}{ "Bronze" group } \\
\hline 1 & Mari El Republic & Penza region & $\begin{array}{l}\text { Republic } \\
\text { Mordovia }\end{array}$ & $\begin{array}{l}\text { Republic of the } \\
\text { Sakha }\end{array}$ & $\begin{array}{l}\text { Republic } \\
\text { Mordovia }\end{array}$ \\
\hline 2 & Tomsk region & $\begin{array}{l}\text { Yamalo-Nenets } \\
\text { Autonomous } \\
\text { District }\end{array}$ & $\begin{array}{l}\text { Republic } \\
\text { Adygeya }\end{array}$ & $\begin{array}{l}\text { Republic } \quad \text { of } \\
\text { Mordovia }\end{array}$ & Chechen Republic \\
\hline 3 & Kursk region & Tomsk region & $\begin{array}{l}\text { Zabaikalye } \\
\text { territory }\end{array}$ & $\begin{array}{l}\text { Zabaikalye } \\
\text { territory }\end{array}$ & $\begin{array}{l}\text { Zabaikalye } \\
\text { territory }\end{array}$ \\
\hline 4 & Oryol region & Kursk region & Chechen Republic & Chechen Republic & Oryol region \\
\hline 5 & Kemerovo region & $\begin{array}{l}\text { Republic } \\
\text { Dagestan }\end{array}$ & Republic of Komi & Tambov region & Tambov region \\
\hline
\end{tabular}

Accordingly, taking into account the peculiarities of the territory will imprint on the formation of marketing strategies and cluster projects in the tourist sphere. For individual regions, emphasis can be placed on the economy and geography of the territory, naturalrecreational and climatic specifics, history and architecture, unique attractions, organization of recreation and entertainment, etc. For example, cultural and cognitive tourism takes place in the Archangel, Murmansk region, Krasnodar region and Crimea, the Republics of Karelia, Tuva, Saha (Yakutia); In Krasnodar and Altay regions, the Republic of Buryatia and Stavropol territory, Zabaikalye and Kaliningrad regions - medical and health tourism; Ecological tourism is common in the Republic of Saha (Yakutia), Primorskiy region, Khabarovsk, Kamchatsky and Krasnoyarsk regions, the Irkutsk region and the Republic of Buryatia, Khanty-Mansi Autonomous District; In the Archangel region and the Republic of Karelia pilgrimage; In Khanty-Mansi, Chukotka, Yamalo-Nenets autonomous Districts - ethnographic tourism; In Moscow,
St. Petersburg, Krasnodar region, Sverdlovsk and Novosibirsk regions - business tourism, etc. [4].

The assessment of Russian tourism potential is reflected in the annual report of the World Economic Forum on Tourism and Travel "The Travel \& Tourism Competitiveness", Report 2017. According to 2017, the share of tourism in Russia's GDP was 5.7\%; Total tourism competitiveness index 4.15 (Russia ranked 41 out of 134 countries); Business environment index - 4.09; Price competition index - 5.75; Safety index -4.31 ; Health and Hygiene Index - 6.70; Turnover in the tourism sector for the year amounted to $\$ 11759$ million; Number of tourists per year - 29848 thousand people [5].

Application of marketing tools in the framework of the regional cluster policy requires the priority definition of clusters of the region (in case of business tourism mechanism), including taking into account the potential of the general tourism industry (in case of development of entertainment tourist direction). This is due to the understanding that the tourism industry is one of the industry leaders in the level of multiplier influence on the 
economic development of the territories: in many leading economies of the world, tourism occupies one of the key, budget-forming positions. As an example of the application of marketing tools, although their purpose is rather narrow, marketing research services, development and promotion of umbrella brands of regional clusters, branding, positioning and promotion of new products (services) of small and medium-sized businesses offered to participants of tourism and recreational cluster in the Center of cluster development of the Murmansk region can be mentioned [6].

Currently, the regions are not only developing business and entertainment tourism within the framework of socioeconomic development plans of their territories but are increasingly initiating and supporting clusters of tourism specialization.

The tourism cluster determines as key activities:

- the development of the tourism industry in the regions;

- the creation of infrastructural conditions for comfortable tourism;

- the increasing of the flow of Russian and foreign tourists in the regions;

- the implementation of technological innovation in the tourism industry through effective collaboration between science, education, business and government.

The developed and currently introduced tourism clusters are presented in Table 2 .

Table 2 Current and aspiring tourism clusters in Russia [7, 12, 13]

\begin{tabular}{|l|c|c|c|}
\hline \multicolumn{1}{|c|}{ Cluster / region } & $\begin{array}{c}\text { Creation } \\
\text { year }\end{array}$ & $\begin{array}{c}\text { Number of } \\
\text { participants }\end{array}$ & $\begin{array}{c}\text { Support by the center for cluster } \\
\text { development in the framework of the } \\
\text { program of the Ministry of economic } \\
\text { development of the Russian Federation } \\
\text { to support small and medium-sized } \\
\text { businesses }\end{array}$ \\
\hline $\begin{array}{l}\text { Tourist and recreational cluster "Northern mosaic", } \\
\text { Republic of Sakha (Yakutia) }\end{array}$ & 2011 & 11 & Yes \\
\hline $\begin{array}{l}\text { Tourist and recreational cluster "Ryazan", Ryazan } \\
\text { region }\end{array}$ & 2011 & 12 & No \\
\hline Tourist cluster of the Vologda region & 2014 & 32 & Yes \\
\hline Tourist cluster of the Novgorod region & 2014 & 27 & Yes \\
\hline $\begin{array}{l}\text { Tourist and recreational cluster of the Murmansk } \\
\text { region }\end{array}$ & 2015 & 12 & Yes \\
\hline Tourist cluster of the Oryol region & 2016 & 21 & No \\
\hline Tourist cluster of the Smolensk region & 2017 & 13 & - \\
\hline Cluster of the tourism industry in the Rostov region & 2017 & 10 & - \\
\hline Tourist cluster "Western Moscow region" & 2019 & - & - \\
\hline Tourist cluster "Volga sea" Tver region & 2019 & - & - \\
\hline $\begin{array}{l}\text { Tourism cluster "On the great tea road" Republic of } \\
\text { Buryatia }\end{array}$ & 2019 & - & - \\
\hline $\begin{array}{l}\text { Tourist cluster "Volga Bulgaria" Republic of } \\
\text { Tatarstan }\end{array}$ & 2019 & - & \\
\hline $\begin{array}{l}\text { Bryansk tourist cluster } \\
\text { Sonuary }\end{array}$ & 2020 & - & \\
\hline
\end{tabular}

Some tourism clusters have concomitant specializations that allow the use of basic specialization opportunities in the practice of these areas. For example, the tourist cluster of the Smolensk region has identified educational services, food, beverage and tobacco production, transport and logistics as related specializations. The tourist and a recreational cluster of the Murmansk region identifies the following areas in support of the key specialization: business services, environmental protection and waste processing, health care and provision of social services, production of food, beverages and tobacco products, agriculture and fisheries, construction, urban economy, architecture, and technical tests, transport and logistics. Strategic marketing developments take into account the peculiarities of the territory of the tourist cluster, which allow to highlight the uniqueness of the offer. Thus, the Tourist and recreational cluster "Northern Mosaic" of the Republic of Saha (Yakutia) as tourist products will present the complex "Rehabilitation Center" Tabaginsky Cape, "the complex" Kingdom of Yakut Winter, "Architectural and ethnographic complex" Uranhai-Saha, "a number of ethnocomplexes - "Evenki", "Dolgans", "Yakuts", "Yukagirs", "Chukchi", representative offices of uluses, etc. The tourist and recreational cluster "Ryazanskiy" focuses on the museum-reserve of S.A. Esenin. Projects of the tourist cluster of Vologda region focus on such main subclusters as Great Ustyug (project "Great Ustyug - the homeland of Father Christmas"); Priozernaya (Belozersk) and North Fivaida (Kirilovsky district); "Vologda cultural capital of the Russian North" (Nason - City project); "Cherepovets - the hot heart of the North"; Active tourism zone "Onego".

When forming a tourism cluster, the authorities should take into account the unified requirements of tourism marketing, which have a certain impact on the efficiency of tourism industry development, complementing them with appropriate infrastructure facilities. These requirements include [8]: 
- natural recreational and climatic attractiveness of the territory;

- cultural-historical resources of the territory and its architecture;

- the quality standard of hotels and tourist accommodation facilities, organization of meals and all the sphere of services and leisure, compliance with the world standards of the tourist infrastructure available in the area, availability and variety of excursion and cultural and entertainment programs;

- quick transport and information accessibility to attractions and places of a business interest;

- political stability in the region and the guarantee of personal security;

- international fame and prestige of the place (image of the territory).

The relevance and expediency of the application of marketing strategic research in the tourism industry was expressed in the consolidated plan of the investment project for the creation of a tourism cluster, introduced by the Federal Tourism Agency into the Methodological Recommendations for the Compilation of a Consolidated Plan of the Investment Project for the Creation of a Tourism Cluster within the framework of the Federal Target Program "Development of Domestic and Entry Tourism in the Russian (2019-2025 years)" [9]. The document defines that in the development of such an investment project it is necessary to carry out marketing analysis, prepare a concept and determine forecast quantitative indicators of the results of the project implementation, draw up a plan for the creation of a tourism cluster and carry out the financial and economic justification of the project. With this systemic approach, tourism marketing will contribute to the positioning and promotion of services produced by tourism clusters within and outside the region, as well as the tourism clusters themselves in the inter-territorial and national space.

Some regions are the regions with great tourism potential, for example, the Krasnodar region. It makes it possible to create cluster initiatives in the tourism industry. Local territories of the regions are also considered as cluster projects, such as Gurievsky municipal district of Kemerovo region, which has defined agro-tourism and ecotourism as tourist destinations, Orthodox tourism [12] as well as associations of individual municipalities - so, Odintsovsky and Ruzskiy city districts in the West of the Moscow region created a tourist cluster "Western Moscow region" [13].

\section{CONCLUSION}

In summary, it should be emphasized the unique systemic nature of the tourism industry which is to the complexity and a large number of relations between elements and subsystems whose activities are aimed at achieving a common goal. In this case, the implementation of marketing strategies by regional authorities into the cluster trajectory of the tourism industry is appropriate and meets modern market trends. Successful realization of the goal is possible only with systematic consolidation of efforts and coordination of actions of all participants of tourist interactions, which should be facilitated by carrying out complex marketing research in this sphere, development of strategic projects within the framework of the unified cluster policy of the territory.

\section{REFERENCES}

[1] A.M. Kiseleva, Marketing of territories of cluster development: regional aspect, in: Bulletin of Omsk University, 2017, no. 3, p. 183-191. DOI: https://doi.org/10.25513/1812-3988.2017.3.183-191

[2] D.V. Vizgalov, Marketing of the city, Moscow, Foundation "Institute of city Economics", 2008, 110 p.

[3] Promotion of tourism development in Russian regions - new opportunities, URL: http://docplayer.ru/30426250-Stimulirovanie-razvitiyaturizma-v-rossiyskih-regionah-novyevozmozhnosti.html (date of access: 16.03.2019)

[4] Tourism in Russia, URL: http://sokolov33.ru/index.php/vidy-turizma (date of access: 12.03.2019)

[5] Tourism statistics and an overview of countries of the world, URL: http://stattur.ru/statistics.php (date of access: 12.03 .2019 )

[6] Center for cluster development of the Murmansk region, URL: http://murmancluster.ru/service (date of access: 14.03.2019)

[7] Map of clusters in Russia, URL: http://map.cluster.hse.ru/list (date of access: 14.03.2019)

[8] A.M. Kiseleva, Marketing strategy of the territory in the investment policy of the city, in: Strategic Management: International Journal of Strategic Management and Decision Support Systems in Strategic Management, 2017, Vol 22, No.1, pp. 22-29

[9] The Website Of The Federal Tourism Agency, URL: https://www.russiatourism.ru/urgent/15561/ ?sphrase_id=462797 (date of access: 14.03.2019)

[10] A.M. Kiseleva, Marketing of territories of cluster development: regional aspect, in: Bulletin of Omsk University, 2017, no. 3, p. 183-191. DOI: https://doi.org/10.25513/1812-3988.2017.3.183-191

[11] National tourist ratings 2015, 2016, 2017, 2018, 2019, URL: http://russia- 
rating.ru/info/category/\%d1\%81\%d0\%bf\%d0\%b5\%d1 \%86\%d0\%bf\%d1\%80\%d0\%be\%d0\%b5\%d0\%ba\%d1 \%82\%d1\%8b (date of access: 14.03.2019)

[12] Territorial clusters. News digest, Vol. 1., January 2020, 20 p., URL: https://cluster.hse.ru/mirror/pubs/ share/341246454 (date of access: 14.02.2020)

[13] Territorial clusters. News digest. Vol.11, November 2019, 16 p., URL: https://cluster.hse.ru/ mirror/pubs/share/341246454 (date of access: 14.02.2020)

[14] M.E. Porter, Reshaping Regional Economic Development: Clusters and Regional Strategy, URL: http://www.hbs.edu/faculty/Pages/item.aspx?num=4805 9 (date of access: 28.02.2020).

[15] P.J. Galvin, Local Government and ClusterRelated Innovation Policy: Two Industry Clusters in the City of Toronto, in: Thesis of Dissertation. University of Exeter, 2011, 328 p., URL:

http://hdl.handle.net/10036/3468 (date of access: 02.02.2014).

[16] N.E. Bondarenko, Cluster theory of economic development: the history of formation and formation, in: International scientific journal "Symbol of science", 2016, No. 2, pp. 116-121.

[17] T.P. Danko, E.S. Kutsenko, Main approaches to identifying clusters in the regional economy, in: Problems of modern economy, 2012, No. 1, pp. 248254.
[18] Ö. Sölvell, G. Lindqvist, C. Ketels, The Cluster Initiative Greenbook, The Competitiveness Institute/VINNOVA, Gothenburg, 2003, 94 p.

[19] J. Swords, Michael Porter's Cluster Theory as a Local and Regional Development Tool - The Rise and Fall of Cluster Policy in the UK, in: Local Economy, 28 (4), 2013, pp. 367-381, URL: http://nrl.northumbria. ac.uk/11207/ (date of access: 30.05.2017)

[20] O.V. Kostenko, Regional cluster policy: monograph, Kirov, 2016, 162 p.

[21] T.V. Sachuk, Territorial marketing as a factor of regional management, in: Abstract for the degree of doctor of Economics, St. Petersburg, 2006, 42 p.

[22] F. Kotler, D. Haider, I. Rein, Marketing Places: Attracting Investment, Industry and Tourism to Cities, States and Nations, Free Press, 2002, 400 p.

[23] A.P. Pankrukhin, Marketing reserves of Russian tourist destinations, in: Practical marketing, 2012, No. 8, pp. 4-16.

[24] A.A. Simavonyan, Promotion and marketing of tourism, in: Management and economy in the XXI century, 2015, No. 2, URL: https:/cyberleninka.ru/ article/n/prodvizhenie-i-marketing-turizma (date of accessa: 09.03.2020).

[25] F. Kotler, K. Asplund, I. Rein, D. Haider, Marketing places. Attracting investment, businesses, residents and tourists to cities, communes, regions and countries in Europe, Saint Petersburg: publishing house "Stockholm school of Economics", 2005, 382 p. 